\title{
Evaluation on performance and SME's productivity with discrete system simulation approach
}

\author{
M. Iqbal Sabit ${ }^{*}$, Reno Dias Anggara Purba, and Joko Sulistio \\ Department of Industrial Engineering, Faculty of Industrial Technology, Indonesia
}

\begin{abstract}
Inventory becomes one of important aspects to identify whether a company has fulfilled the consumers' demands or not. Shortage of stock, finished goods particularly could emerge the failure of accomplishing the target of consumers' demand that could also lead to loss of sales. Therefore, it needs good inventory control. This paper is objected improve SME's productivity by using the approach of discrete system simulation of aluminum industry that rapidly developed in Yogyakarta. Simulation is one of the appropriate tools for experiments that purposed to identify best response from system components. Based from Observation from line production, there are semi-finished products were not finished. Other than that the firm has no clue to solve the problem. Design of experiment and scenario are developed in a model that was built to obtain solution in enhancing the performance and productivity. As the result of initial performance that is not optimal, rescheduling on transporter schedule and the replenishment of machines and operators on the lathing process could be performed as improvements to enhance the productivity. This experiment can be used as the solution in improving the product's output as $64.36 \%$.
\end{abstract}

\section{Introduction}

Recently, the numbers of micro, small and medium enterprises' actors in Indonesia have increased massively among other countries since 2014. The numbers keep growing in 2015, 2016 up to 2017. There are 57,8 million and growing of MSME's actors in the next few years as stated by Ministry of Cooperatives and SMEs recorded in 2014 (Ministry of Cooperatives and SMEs, 2014).

From the perspective of economics sector, MSMEs that have the biggest business unit, consecutively are agriculture sector, livestock, forestry and fishery $(48,85 \%)$, trading, hotel and restaurant $(28,83)$; transportation and communication $(6,88 \%)$, processing industry $(6,41 \%)$, services $(4,52 \%$; financial, renting and company services $(2,37 \%)$; construction $(1,57 \%)$; mining and excavation $(0,53 \%)$; electricity, gas and clean water $(0,03 \%)$. One of the MSMEs that could possibly developing rapidly is aluminum processing industry (Bank of Indonesia, 2015).

Special Region of Yogyakarta (DIY) has huge potential in aluminum. DIY is the biggest pan's producer. Around 15.000 pans are produced by 10 companies in DIY (Okezone Finance, 2016). One of the SMEs companies that engages in aluminum processing is SP Aluminum.

SP Aluminum is the company of casting, smelting and household appliances' manufacturing that made from aluminum, such as: frying pans, saucepan, cormorant and other pans. Later, the research will be only focused on the manufacturing of frying pan. Production system is determined as make to order repetitive, which means that the company will produce the products based on consumers' orders, but the company also will produce numbers of frying pans as stocks.

According to Nasution (2008), production planning has specific purpose to provide optimum decision based on available resources in company to fulfill products' demand. Hence, it considers as action to balance company's demands and supplies. Stock is considered as the important factor to decide whether the company has fulfilled the consumers' demands or not. Shortage of stock particularly finished goods could emerge the failure in accomplishing the target of consumers' demand that could also lead to loss of sales. On the contrary, the excessive stocks could cause additional cost. Therefore, it needs good inventory management as the control process in regulating the stocks. Besides, from observation, there are stacks of half-finished goods in every production department that indicates the poor performance of company's production system.

Based on existing above problem, therefore a simulation method is used to solve problems in production floor, through this simulation method, a model will be constructed to represent real system on the production system at SP Aluminum.

\section{Method}

This research applies qualitative descriptive method. The data are primary data that was obtained from observation and interview result. The data are used to form system behavior to simulate model from real system. The subject of the experiment is discrete event simulation. Discrete

* Corresponding author: 15522331@students.uii.ac.id 
event simulation (DES) is a flexible modeling method characterized by the ability to represent complex behavior within, and interactions between individuals, populations, and their environments (Pidd, 2004). According to Banks (2000), simulation is the imitation of real system operation in the unit time, where simulation involves history from system to draw conclusion out of real system characteristics. Simulation is used before an existing system is altered or a new system built, to reduce the chances of failure to meet specifications, to eliminate unforeseen bottlenecks, to prevent under or overutilization of resources, and to optimize system performance (Maria, 1997).

The first thing to be conducted is process time data collecting for every production process. These data are employed to find out the distribution of process time data to establish model, so it can represent the real system. Based on above data, then a model is constructed by using flexim 6.0 software as the simulation assisting tools towards constructed model. Finally, it can be resumed the final output as result of simulation that will be the validation reference for simulation model's result that has the fitness with observed real system. The manner in which a model is implemented determines the range and level of outputs that can be used in the validation and final analyses (Karnon, 2012), two-sided test of equality and two variances test of equality will be the methods to be applied. Besides, from simulation, the performance of SMEs could be obtained and employed as data to be further analyzed as a basis of determination on new policies in solving existing problems. The alternative of selection is applied for better policy out of other offered policies by implementing ANOVA test as condition to conduct the next test, which is bonferoni test.

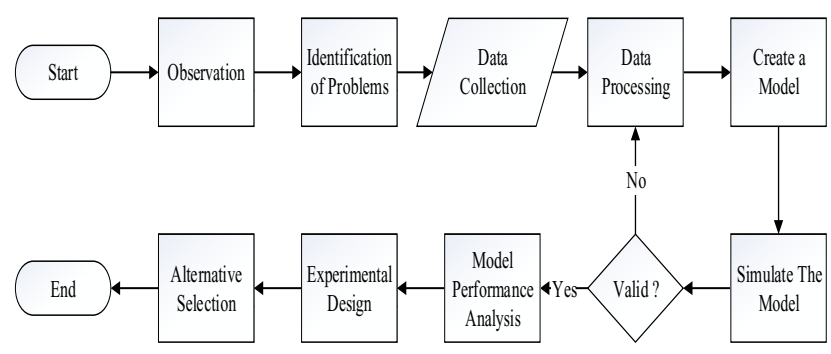

Fig. 1. Scheme of research methodology

\subsection{Object of Research}

Researcher only focuses on production process of thin frying pan manufacturing with dimension of $12,14,15$, $16,18,20$ and 24 with type of plain and polished frying pans. The production process in SP Aluminum covers 7 stages, which are material smelting (aluminum bar), stamping, quality control 1 , finishing 1 (grinders and files), finishing 2 (lathing and polishing), quality control 2 and final stage of finishing 3 (numbering and labeling). The sequence of production process for all jobs are the same from starting stage to the final one.

\section{Result}

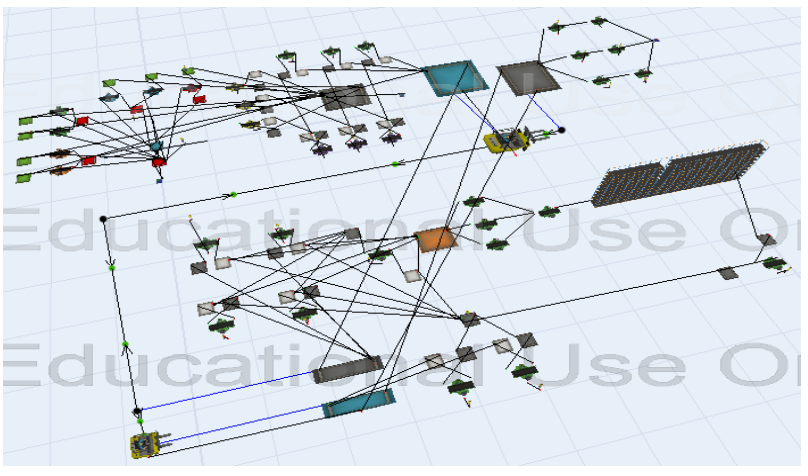

Fig. 2. Model Built in Flexsim

After the model is constructed, then the credibility will be enhanced by performing the validation. Following historical data were obtained from all seven types of frying pans in 30 days of production. Validation process will apply two-sided of equality test and two variance of equality test, to assess whether the resulted simulation model will have the fitness with observed real system.

Table 1. Historical Output Data and Simulation

\begin{tabular}{llllllll}
\hline Historical & & \multicolumn{5}{c}{ Simulation } \\
\hline Data of- & \multicolumn{3}{c}{$\begin{array}{l}\text { Data } \\
\text { of- }\end{array}$} & \multicolumn{3}{c}{$\begin{array}{l}\text { Data } \\
\text { of- }\end{array}$} & $\begin{array}{l}\text { Data } \\
\text { of- }\end{array}$ \\
$\mathbf{1}$ & 500 & $\mathbf{1 6}$ & 500 & $\mathbf{1}$ & 505 & $\mathbf{1 6}$ & 500 \\
$\mathbf{2}$ & 490 & $\mathbf{1 7}$ & 500 & $\mathbf{2}$ & 505 & $\mathbf{1 7}$ & 504 \\
$\mathbf{3}$ & 480 & $\mathbf{1 8}$ & 480 & $\mathbf{3}$ & 500 & $\mathbf{1 8}$ & 500 \\
$\mathbf{4}$ & 510 & $\mathbf{1 9}$ & 530 & $\mathbf{4}$ & 504 & $\mathbf{1 9}$ & 550 \\
$\mathbf{5}$ & 500 & $\mathbf{2 0}$ & 500 & $\mathbf{5}$ & 504 & $\mathbf{2 0}$ & 502 \\
$\mathbf{6}$ & 500 & $\mathbf{2 1}$ & 490 & $\mathbf{6}$ & 504 & $\mathbf{2 1}$ & 500 \\
$\mathbf{7}$ & 510 & $\mathbf{2 2}$ & 540 & $\mathbf{7}$ & 500 & $\mathbf{2 2}$ & 550 \\
$\mathbf{8}$ & 490 & $\mathbf{2 3}$ & 550 & $\mathbf{8}$ & 505 & $\mathbf{2 3}$ & 550 \\
$\mathbf{9}$ & 450 & $\mathbf{2 4}$ & 540 & $\mathbf{9}$ & 454 & $\mathbf{2 4}$ & 527 \\
$\mathbf{1 0}$ & 500 & $\mathbf{2 5}$ & 510 & $\mathbf{1 0}$ & 504 & $\mathbf{2 5}$ & 500 \\
$\mathbf{1 1}$ & 460 & $\mathbf{2 6}$ & 500 & $\mathbf{1 1}$ & 455 & $\mathbf{2 6}$ & 502 \\
$\mathbf{1 2}$ & 500 & $\mathbf{2 7}$ & 450 & $\mathbf{1 2}$ & 504 & $\mathbf{2 7}$ & 455 \\
$\mathbf{1 3}$ & 510 & $\mathbf{2 8}$ & 460 & $\mathbf{1 3}$ & 500 & $\mathbf{2 8}$ & 454 \\
$\mathbf{1 4}$ & 490 & $\mathbf{2 9}$ & 510 & $\mathbf{1 4}$ & 500 & $\mathbf{2 9}$ & 503 \\
$\mathbf{1 5}$ & 520 & $\mathbf{3 0}$ & 520 & $\mathbf{1 5}$ & 505 & $\mathbf{3 0}$ & 505 \\
\hline & & & & & & &
\end{tabular}

First validation is conducted by testing the similarity of two means data of simulation result with real system data. After the calculation of statistics test is conducted, it can be resumed that $Z$ count is -0.325455019 . According to the calculation criteria stated that since $-\mathrm{Z}(0.025)<\mathrm{Z}$ count $<\mathrm{Z}(0.025)$, which is: $-1.96<\mathrm{Z}$ count $<1.96$. Hence, $\mathrm{H}_{0}$ is accepted, which means that the output mean of real system is similar with output mean of simulation model.

Second validation is conducted by testing the similarity of two variance data of simulation result with 
real system. After F count is calculated, the result of F count is found as 1.038072 , according to the criteria of testing, since $\mathrm{F}_{0,975}<\mathrm{F}$ count $<\mathrm{F}_{0,025}$ which is: $0.475965<$ $1.038072<2.100996$. Hence, $\mathrm{H}_{0}$ is considered as accepted, which means that the output mean of the real system is similar with the output mean of simulation model.

On the both similarity tests, model is considered as valid. Therefore, the result of model could be assumed as representative to represent real model. Later, it can be applied to improve the performance of SMEs.

\section{Discussion}

Table 2. Simulation Report

\begin{tabular}{rcc}
\hline \multicolumn{3}{c}{ Model Stop Time: 28800} \\
Object & Class & State_Content \\
\hline Queue Lathe 1 & Queue & 31 \\
Queue Lathe 2 & Queue & 65 \\
Queue Lathe 3 & Queue & 394 \\
Queue Lathe 4 & Queue & 237
\end{tabular}

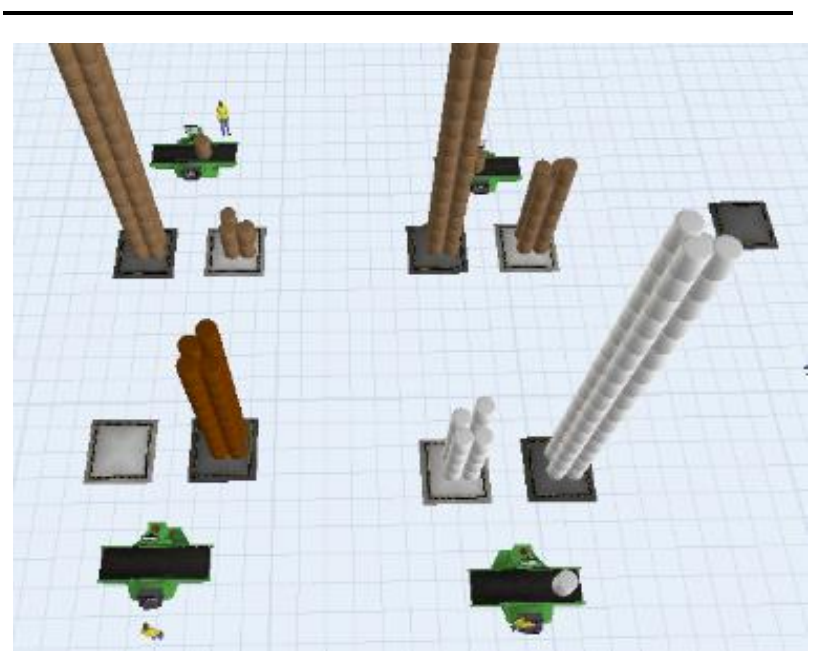

Fig. 3. Problem state

Based from Observation from line production, there are semi-finished products were not finished. Other than that the firm has no clue to solve the problem. Therefore using discrete system simulation could find cause of the problem. Based on the summary report, in the lathe process department, there was frying pans' shelter where they will be forwarded to the lathe machine for being processed. Nevertheless, based on the state content, there were numbers of flow items that left behind when the simulation ended. This was caused by limited time of process and the capacity to process lots of flow items, on the other hand, flow items that were carried by transporters from products' shelter of finishing 1 to the shelter of finishing 2 considered to have wide schedule, at 09.00 , at 12.00 , at 14.00 and at 15.30 , those are the only times to accommodate the drop of the flow items. Therefore, process in finishing 2 will also experience

postponement for loading and processing so it will also be effected the results of final production output.

\subsection{Design of Experiment}

Improvement is made on the first scenario to enhance final input of finished products, where rescheduling on transporters is applied with the additional of extra schedule, which is at 10.00 . While on the second scenario, the additional machines for lathing process department are placed subjected to reduce state content with the combination of first scenario.

PFM1

\begin{tabular}{|c|c|c|c|c|}
\hline & Mean ( $90 \%$ Confidence) & Sample Standard Deviation & Min & Max \\
\hline Scenario 1 & $753.79<766.9<780.01$ & 42.27 & 700 & 850 \\
\hline Scenario 2 & $803.93<814.4<824.87$ & 33.76 & 762 & 868 \\
\hline Scenario 3 & $826.34<835.8<845.26$ & 30.5 & 803 & 904 \\
\hline
\end{tabular}

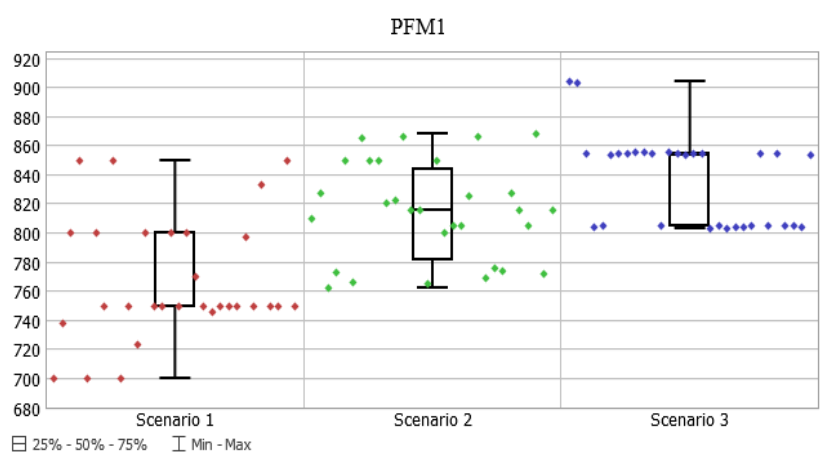

Fig. 4. The improvement of output's number

\subsection{Alternative Selection}

Based on the design of experiment's result, scenario 1 and scenario 2 are suggested to be able to improve final output of production process. In determining policies that will be decided, alternative selection based on comparison of scenarios' final output will be performed. Below is the replication table of simulation results from both scenarios.

Table 3. Design of Experiment's Result

\begin{tabular}{|c|c|c|c|c|c|c|c|c|c|c|c|}
\hline \multicolumn{4}{|c|}{ Initial Model } & \multicolumn{4}{|c|}{ Design of Experiment 1} & \multicolumn{4}{|c|}{ Design of Experiment 2} \\
\hline $\begin{array}{c}\text { Data } \\
\text { of- }\end{array}$ & & $\begin{array}{c}\text { Data } \\
\text { of- }\end{array}$ & & $\begin{array}{c}\text { Data } \\
\text { of- }\end{array}$ & & $\begin{array}{c}\text { Data } \\
\text { of- }\end{array}$ & & $\begin{array}{c}\text { Data } \\
\text { of- }\end{array}$ & & $\begin{array}{c}\text { Data } \\
\text { of- }\end{array}$ & \\
\hline 1 & 505 & 16 & 500 & 1 & 753 & 16 & 754 & 1 & 900 & 16 & 900 \\
\hline 2 & 505 & 17 & 504 & 2 & 754 & 17 & 800 & 2 & 900 & 17 & 900 \\
\hline 3 & 500 & 18 & 500 & 3 & 805 & 18 & 804 & 3 & 900 & 18 & 900 \\
\hline 4 & 504 & 19 & 550 & 4 & 805 & 19 & 754 & 4 & 900 & 19 & 900 \\
\hline 5 & 504 & 20 & 502 & 5 & 754 & 20 & 804 & 5 & 900 & 20 & 900 \\
\hline 6 & 504 & 21 & 500 & 6 & 755 & 21 & 755 & 6 & 900 & 21 & 900 \\
\hline 7 & 500 & 22 & 550 & 7 & 755 & 22 & 753 & 7 & 900 & 22 & 900 \\
\hline 8 & 505 & 23 & 550 & 8 & 803 & 23 & 804 & 8 & 904 & 23 & 900 \\
\hline 9 & 454 & 24 & 527 & 9 & 753 & 24 & 755 & 9 & 900 & 24 & 900 \\
\hline 10 & 504 & 25 & 500 & 10 & 755 & 25 & 755 & 10 & 900 & 25 & 900 \\
\hline 11 & 455 & 26 & 502 & 11 & 754 & 26 & 755 & 11 & 900 & 26 & 900 \\
\hline 12 & 504 & 27 & 455 & 12 & 753 & 27 & 754 & 12 & 900 & 27 & 855 \\
\hline 13 & 500 & 28 & 454 & 13 & 753 & 28 & 755 & 13 & 900 & 28 & 900 \\
\hline 14 & 500 & 29 & 503 & 14 & 755 & 29 & 754 & 14 & 900 & 29 & 900 \\
\hline 15 & 505 & 30 & 505 & 15 & 804 & 30 & 755 & 15 & 900 & 30 & 904 \\
\hline
\end{tabular}


To choose the best alternative, anova test is firsly performed on output of each scenario. Based on data of table 3, anova results are listed, as follows:

- $\mathrm{H}_{0}$ : There is no difference on output mean among three designs of experiment.

- Ha: There is difference on output mean among three designs of experiment.

Table 4. Anova Test

\begin{tabular}{lllll} 
SUMMARY & & & & \\
\hline Groups & Count & Sum & Mean & Variance \\
\hline Model Awal & 30 & 15051 & 501.7 & 574.5621 \\
D.E 1 & 30 & 23022 & 767.4 & 494.731 \\
D.E 2 & 30 & 26963 & 898.7667 & 69.35747 \\
\hline
\end{tabular}

\begin{tabular}{lllllll}
\hline ANOVA & \multicolumn{5}{ll}{} & \\
\hline Source of Variation & SS & Df & $M S$ & $F$ & $P$-value & $F_{\text {c crit }}$ \\
\hline Between Groups & 2455156 & 2 & 1227578 & 3234.297 & $2.22056 \mathrm{E}-82$ & 3.101296 \\
Within Groups & 33020.87 & 87 & 379.5502 & & & \\
Total & 2488177 & 89 & & & &
\end{tabular}

From table 4 above, it suggested that if $\mathrm{f}$ count $>\mathrm{f}$ table, hence based on testing criteria, $\mathrm{H}_{0}$ is rejected, then there is the difference on output mean among three designs of experiment. The difference becomes the condition for Bonfferoni test as advance step in selecting the alternatives. Then, the best alternative will be chosen by performing bonffernoni test under following hypothesis:

Ho : if there is output mean that effected among design of experiment

Ha : if there is no difference on output mean that affected among experiments

Testing criteria:

Ho is accepted, if $\mathrm{P}(\mathrm{T}<=\mathrm{t})$ two-tail $<\alpha / \mathrm{n}$

Ho is rejected, if $\mathrm{P}(\mathrm{T}<=\mathrm{t})$ two-tail $>\alpha / \mathrm{n}$

1 Initial model and Design of Experiment 1

Based on calculation, it is obtained that $\mathrm{P}(\mathrm{T}<=\mathrm{t})$ one-tail $(1.7953 \mathrm{E}-46)<\mathrm{alfa} / \mathrm{n}(0.016666667)$, then $\mathrm{H}_{0}$ is accepted, which means that there is significant difference on mean between initial model output with the design of experiment 1

2 Initial model and Design of Experiment 2 Based on calculation, it is obtained that $\mathrm{P}(\mathrm{T}<=\mathrm{t})$ one-tail (1.72063E-62) < alfa/n (0.016666667), then $\mathrm{H}_{0}$ is accepted, which means that there is significant difference on mean between initial model output with the design of experiment 2

3 Design of Experiment 1 \& Design of Experiment 2

Based on calculation, it is obtained that $\mathrm{P}(\mathrm{T}<=\mathrm{t})$ one-tail (3.01E-37) < alfa/n (0.016666667), then $\mathrm{H}_{0}$ is accepted, which means that there is significant difference on mean between output of design of experiment 1 with the design of experiment 2

Based on statistics calculation by comparing all three final outputs from three alternatives, it can be stated that there is difference on final output's mean that resumed by three alternatives. It also can be listed the mean on each alternative for initial model, design of experiment 1 and design of experiment 2 consecutively: 499,6, 767,4 and
898,76 . From those means, it can be concluded that design of experiment 2 has the biggest mean if compared with others. Hence, it can be suggested that the company could employ design of experiment 2 as alternative to increase its final output significantly.

\section{Conclusion}

Initial performance of company is considered as not optimal, which was showed by numbers of flow items that was stacked in lathing department by the time the simulation was ended. It was caused by the process allocation time and capacity, other than that, transporter's scheduling is the main factor of state content on the processed flow items. Based on the result of that initial performance, rescheduling on transporter schedule and the replenishment of machines and operators on the lathing process are suggested as improvements to enhance the productivity. This experiment can be used as the solution in improving the product's output as $64,36 \%$.

\section{References}

1. Bank Indonesia. Profil Bisnis Usaha Mikro, Kecil Dan Menengah (UMKM). Retrieved June 18, 2017, from www.bi.go.id, (2015)

2. Banks, J., Carson, J., Nelson, B., \& Nicol, D. Discrete event system simulation 3rd edition. Englewood Cliffs, (2000)

3. Karnon, J. Modeling using Discrete Event Simulation: A Report of the ISPOR-SMDM, Value In Health, (2012)

4. Kementrian Negara Koperasi dan Usaha Kecil dan Menengah, Peran Usaha Mikro, Kecil dan Menengah dalam Pembangunan Ekonomi Nasional. Retrieved June 18, 2017, from www.depkop.go.id, (2014)

5. Maria, A. Introduction to Modeling and Simulation. Proceedings of the Winter Simulation Conference, (1997)

6. Nasution, A., \& Prasetyawan, Y. Perencanaan dan Pengendalian Produksi Edisi Pertama. Yogyakarta: Graha Ilmu, (2008)

7. Okezone Finance Retrieved June 10, 2017, from http://economy.okezone.com/read/2016/06/14/320/1 414532/yogya-jadi-produsen-terbesar-wajan-diindonesia, (2016)

8. Pidd, M. Computer Simulation in Management Science (5th ed). John Wiley \& Sons, (2004) 